\title{
Toxigenicity of Some Fusaria Associated with Plant and Human Diseases in the Malaysian Peninsula
}

\author{
By B. SALLEH† AND R. N. STRANGE* \\ Department of Biology, Darwin Building, University College London, Gower Street, \\ London WC1E 6BT, UK
}

(Received 1 September 1987)

\begin{abstract}
In the course of a plant disease survey of the Malaysian Peninsula (Malaysia comprises the Malaysian Peninsula, Sabah and Sarawak) during the period 1981-1986, more than 1000 isolates of Fusarium were obtained from diseased plants and seeds. Two further isolates were obtained from patients admitted to hospitals in the same area. The occurrences of $F$. proliferatum, $F$. nygamai and $F$. longipes are new records for the Malaysian Peninsula and the association of $F$. solani and $F$. oxysporum var. redolens with human diseases does not seem to have been reported previously. Ten representative species which could be classified into seven sections of the genus were selected for studies of their toxigenicity in liquid cultures and/or on rice. Crude toxin preparations from culture filtrates or extracts of the inoculated rice were tested for toxicity to brine shrimp larvae and tobacco mesophyll protoplasts. The protoplasts were more sensitive than the brine shrimp larvae to the toxin preparations, except those from the isolates of $F$. solani and $F$. oxysporum var. redolens obtained from either humans or tobacco. The toxicity of the preparations from rice cultures per $\mathrm{g}$ rice was always greater than the toxicity per $\mathrm{ml}$ of culture filtrates from cultures grown on Czapek-Dox broth, Czapek-Dox supplemented with $1 \%(\mathrm{w} / \mathrm{v})$ peptone or Czapek-Dox supplemented with $5 \%(\mathrm{w} / \mathrm{v})$ tobacco extract. The activity of all toxin preparations was stable to heat. It is concluded that the occurrence of toxigenic species of Fusarium in the Malaysian Peninsula is widespread and that they may pose a serious threat to the health of human, animal and plant populations.
\end{abstract}

\section{INTRODUCTION}

Fusarium is one of the most ubiquitous genera of plant-pathogenic fungi. Some species can also cause human diseases such as onchomycosis, keratomycosis and skin lesions (Joffe, 1986). Several species of Fusarium produce mycotoxins, i.e. trichothecenes, butenolide, moniliformin and zearalenone, on a variety of substrates (Marasas et al., 1984). These toxic compounds have been implicated in various animal disorders such as fescue foot, leukoencephalomalacia and feed refusal, as well as skin lesions and various haemorrhagic, emetic and estrogenic syndromes (Mirocha et al., 1976, 1977; Tanaka et al., 1986; Ueno, 1980, 1983; Vesonder et al., 1978). They have also been implicated in human diseases such as oesophageal cancer, alimentary toxic aleukia (ATA), Kashin-Beck disease and scabby grain intoxication (Joffe, 1978; Marasas et al., 1981, 1984; Snyder, 1986). The consumption of these mycotoxins has normally been attributed to the contamination of crops both before harvest and during storage by Fusarium spp. Fusarium mycotoxins have also received much attention as potential nonconventional warfare agents in neighbouring countries of the Malaysian Peninsula (Haig, 1982; Mirocha et al., 1982, 1983; Rosen \& Rosen, 1982). Mirocha et al. (1983), for instance, showed that samples of leaves, water, cereal grains, 'yellow rain' and soil, as well as blood, urine and body tissues obtained from alleged chemical warfare victims from Laos and Kampuchea, contained several Fusarium

† Present address: School of Biological Sciences, Universiti Sains Malaysia, Penang 11800, Malaysia. 
mycotoxins ranging from a trace (1.0 p.p.b.) to 143 p.p.m. Toxigenic Fusarium spp. are likely to be more prevalent in tropical countries where both temperature and humidity are high and where crop protection and post-harvest storage conditions may be inadequate. Indeed, they are often found on seeds and as contaminants of foods consumed by man and animals in the Malaysian Peninsula (Gordon, 1960; Salleh \& Sulaiman, 1984; Salleh \& Zunaidah, 1984; Singh, 1973; Thompson \& Johnston, 1953), as well as in Sabah (Liu, 1977; Williams \& Liu, 1976), Sarawak (Turner, 1971) and Singapore (Lim, 1969, 1982). Nevertheless, to date, there have been no reports of human or animal diseases or disorders caused by or associated with Fusarium spp. in Malaysia, nor have there been any reports from this region of toxins produced by these fungi. In this communication we report the occurrence of ten Fusarium species in the Malaysian Peninsula and evidence for their toxigenicity.

\section{METHODS}

Fusarium isolates. Over 1000 isolates of Fusarium were obtained from diseased plants and seeds in the course of a plant disease survey of the Malaysian Peninsula during the period 1981-1986 (Salleh \& Sulaiman, 1984; Din \& Salleh, 1986). From these, fourteen were selected for the present study, together with two isolates from human infections (Table 1). Isolate 381 was originally obtained from a male patient admitted to the General Hospital, Kuala Lumpur, suffering from onchomycosis (nail infections) and isolate 610 originated from a partially blind female patient admitted to the Universiti Sains Hospital in Kubang Kerian, Kelantan, suffering from acute eye keratitis.

All the Fusarium isolates were single spored following the method of Hansen \& Smith (1932) as modified by Salleh \& Sulaiman (1984). Species were identified from cultures growing on potato/sucrose agar using the diagnostic characters described by Booth $(1971,1977)$ and from cultures growing on potato/dextrose agar using the diagnostic characters described by Nelson et al. (1983) after incubation under standard conditions (Salleh \& Sulaiman, 1984). All monoconidial isolates of the fungus were preserved in sterilized sandy-loam soils at $4 \pm 1{ }^{\circ} \mathrm{C}$ (Salleh \& Sulaiman, 1984) and in 10\% (v/v) glycerol in liquid nitrogen at the Fusarium Culture Collection Unit, School of Biological Sciences, Universiti Sains Malaysia. A further set of isolates was also suspended in $10 \%(\mathrm{v} / \mathrm{v})$ glycerol and kept in a liquid nitrogen bank at the Department of Biology, University College London.

Media and culture conditions. Liquid media (100 ml in $250 \mathrm{ml}$ Erlenmeyer flasks) were as follows: modified Czapek-Dox (CD) (Oxoid), modified Czapek-Dox supplemented with $1 \%(w / v)$ Oxoid peptone (CD + $1 \% \mathrm{P})$ or modified Oxoid Czapek-Dox dissolved in $5 \%(w / v)$ tobacco extract $(C D+5 \%$ TE) (prepared by homogenizing $5 \mathrm{~g}$ cleaned roots, stems and leaves of healthy 2-week-old Nicotiana tabacum L. var. TAPM13 in $100 \mathrm{ml}$ distilled water). Isolates obtained from naturally diseased rice or rice seeds were also cultured on $25 \mathrm{~g}$ polished American long-grain rice presoaked with $50 \mathrm{ml}$ distilled water in $250 \mathrm{ml}$ Erlenmeyer flasks. All flasks were plugged with cotton wool, wrapped with two layers of aluminium foil and autoclaved for $20 \mathrm{~min}$ at $121{ }^{\circ} \mathrm{C}$. After storage overnight at room temperature they were inoculated with $1 \mathrm{ml}$ conidial suspension $\left(3 \times 10^{6}\right.$ conidia ml $\left.^{-1}\right)$ of

Table 1. Fusarium isolates from the Malaysian Peninsula screened for toxigenicity

\begin{tabular}{|c|c|c|c|c|}
\hline Isolate & Source & $\begin{array}{l}\text { Location } \\
\text { (state) }\end{array}$ & Species & Section \\
\hline 172 & Rice seed var. Seberang & Penang & pallidoroseum & Arthrosporiella \\
\hline 425 & Tobacco stem rot & Kelantan & pallidoroseum & Arthrosporiella \\
\hline 214 & Potato tubers dry rot & Penang & solani & Martiella \\
\hline 505 & Tobacco root rot & Kelantan & solani & Martiella \\
\hline 527 & Tobacco root rot & Kelantan & solani & Martiella \\
\hline 610 & Human eye keratitis & Kelantan & solani & Martiella \\
\hline 381 & Human onchomycosis & K. Lumpur & $\begin{array}{l}\text { oxysporum } \\
\text { var. redolens }\end{array}$ & Elegans \\
\hline 546 & Tobacco stem lesion & Kelantan & nygamai & uncertain (see text) \\
\hline 349 & Bakanae disease of rice & Penang & proliferatum & Liseola \\
\hline 518 & Tobacco seed var. & & & \\
\hline & TAPM13 & Terengganu & proliferatum & Liseola \\
\hline 447 & Rice seed var. Seberang & Penang & chlamydosporum & Sporotrichiella \\
\hline 188 & Rice seed var. Seberang & Penang & chlamydosporum & Sporotrichiella \\
\hline 456 & Rice seed var. Sitanjung & Penang & avenaceum & Roseum \\
\hline 18 & Chilli stem gall & Penang & longipes & Gibbosum \\
\hline 587 & Water melon soft rot & Perlis & acuminatum & Gibbosum \\
\hline 452 & Rice stem & Penang & concolor & Gibbosum \\
\hline
\end{tabular}


selected Fusarium isolates (Table 1). The conidial suspension was prepared as follows. A few drops of the stock monoconidial isolates preserved in liquid nitrogen were transferred onto potato/dextrose agar plates and incubated on a light bench, illuminated by six fluorescent daylight $65 / 80 \mathrm{~W}$ tubes (Thorn) and one black-light TLD $36 \mathrm{~W}$ tube (Philips) at $27 \pm 2{ }^{\circ} \mathrm{C}$ for 1 week. The conidia were harvested by addition of $5 \mathrm{ml}$ sterile distilled water and gentle agitation. They were counted using a haemocytometer and their concentration was adjusted by further addition of sterile distilled water. Flasks inoculated with sterile distilled water served as controls. All experiments were done in triplicate. Liquid cultures were incubated at $27 \pm 2{ }^{\circ} \mathrm{C}$ on a reciprocal shaker (throw $6.0 \mathrm{~cm}$ and 80 strokes $\min ^{-1}$ ). Rice cultures were incubated on a stationary bench, also at $27 \pm 2{ }^{\circ} \mathrm{C}$, in the dark. Three days after inoculation, the rice cultures were thoroughly mixed with a sterile glass rod, in a laminar-flow cabinet.

Extraction and preparation of crude toxins for bioassay. Cultures were harvested at weekly intervals for 4 weeks. Liquid cultures were filtered through a layer of nylon mesh (mesh size $80 \mu \mathrm{m}$ ) and the number of conidia in the filtrates was counted using a haemocytometer. The $\mathrm{pH}$ of the filtrates was recorded after sedimentation of the conidia in a centrifuge, and the mycelium was recovered from the nylon mesh and dried to constant weight at $90^{\circ} \mathrm{C}$. Rice cultures were homogenized in $100 \mathrm{ml}$ methanol/water $(7: 3, \mathrm{v} / \mathrm{v})$ with a Sorvall Omni-Mixer (5000 r.p.m. for $5 \mathrm{~min}$ ). The homogenate was filtered under vacuum through a glass microfibre filter (Whatman GF/A) and the filtration process repeated in order to clarify the filtrate further if necessary. Solid material remaining on the filters was washed with $10 \mathrm{ml}$ of the aqueous methanol mixture and the washings were added to the filtrates before removal of the methanol by film evaporation. The culture filtrates and rice extracts were immediately freeze-dried and redissolved in $5 \mathrm{ml}$ and $12.5 \mathrm{ml}$ sterile distilled water, respectively. They were clarified by centrifugation at $900 \mathrm{~g}$ for $10 \mathrm{~min}$ and stored at $-70^{\circ} \mathrm{C}$ until required for bioassay.

For the brine shrimp bioassay, the preparations were diluted $1: 1$ with $2 \mathrm{ml}$ double-strength $(2 \times)$ brine shrimp medium (Bergers et al., 1985) and the $\mathrm{pH}$ was adjusted with $1 \mathrm{M}-\mathrm{HCl}$ to $6 \cdot 5$. For the tobacco mesophyll protoplast bioassay, the preparations were diluted $1: 1$ with $2 \times$ CPW $13 \mathrm{M}$ plant protoplast holding buffer formulated by Power \& Chapman (1985) (pH adjusted with $1 \mathrm{M}-\mathrm{HCl}$ to $5 \cdot 8$ ).

Brine shrimp (Artemia salina) larvae assay. Serial twofold dilutions in duplicate of the toxin preparations were made in the wells of a Linbro microtest plate (Flow Laboratories; $100 \mu \mathrm{I}$ per well). Larval suspension $(100 \mu \mathrm{I} ; 20$ 30 larvae per well), hatched by the method of Bergers et al. (1985), was added. Controls consisted of larvae in brine shrimp medium only. Dead larvae were counted immediately and recounted after incubation at $25^{\circ} \mathrm{C}$ in the dark for $24 \mathrm{~h}$. Live larvae were subsequently killed by the addition of one drop of $37 \%(\mathrm{v} / \mathrm{v})$ formalin to each well and the total number of dead larvae was counted.

Tobacco mesophyll protoplast assay. Mesophyll protoplasts of tobacco (Nicotiana tabacum var. TAPM13) were prepared by a modification of the method of Thanutong et al. (1983). The adaxial surfaces of young but fully open and healthy leaves from 2-week-old plants were gently rubbed with wet cotton wool dipped in alumina powder (grade 3/50; Gallenkamp Griffin) and placed on an enzyme solution containing $1 \%$ (w/v) cellulase R10 and 0.05\% (w/v) macerozyme R10 (both enzymes from Kinki-Yakult Mfg Co., Nishimomiya, Japan) in $13 \%$ (w/v) mannitol with the pH adjusted to 5.8 with $0.2 \mathrm{M}-\mathrm{KOH}$. After incubation for $2 \mathrm{~h}$ at $25^{\circ} \mathrm{C}$, the leaves were gently agitated to release the protoplasts and the protoplast suspension was filtered through a layer of nylon mesh $(80 \mu \mathrm{m})$. The protoplast suspension was centrifuged at $20 \mathrm{~g}$ for $2 \mathrm{~min}$, the supernatant removed and the protoplast pellet washed twice on the centrifuge in the same manner with the holding buffer. Protoplasts were counted using a modified Fuchs Rosenthal haemocytometer and the concentration was adjusted to $2 \times 10^{5} \mathrm{ml}^{-1}$.

Toxin preparations dissolved in holding buffer were assayed in the microtest plates as described above, substituting protoplast suspension for brine shrimp larval suspension. After incubation for $2 \mathrm{~h}$ at $25^{\circ} \mathrm{C}$ in the dark, $100 \mu \mathrm{l}$ of $0.1 \%(\mathrm{w} / \mathrm{v})$ phenosafranin in holding buffer was added to each well (Widholm, 1972). Samples $(10 \mu \mathrm{l})$ of the protoplasts from each well were transferred to 12-well microflow slides (Flow Laboratories) and the dead (stained) and live (non-stained) protoplasts counted under a compound microscope.

Expression of results. Results are expressed as units of activity, where 1 unit represented the $\mathrm{LD}_{50}$ value for brine shrimps or protoplasts. Both the $\mathrm{LD}_{50}$ values and the dilution factors which gave these values were obtained from graphs of probit percent mortality, corrected for control values (Strange et al., 1982), plotted against log to the base 2 of the factor by which the toxin had been diluted (Finney, 1980). The number of units per ml of preparation was then calculated by multiplying the dilution factor which corresponded to the $\mathrm{LD}_{50}$ value by 10 , since the wells of the microtest plate contained $100 \mu \mathrm{l}$ of toxin preparation.

\section{RESULTS AND DISCUSSION}

All 16 isolates were identified according to the criteria of Booth $(1971,1977)$ or Nelson et al. (1983) with the exception of isolate 546, which was obtained from a stem lesion of a tobacco plant. This isolate had similar morphological and cultural characteristics to those of $F$. nygamai from Australia (Burgess \& Trimboli, 1986) except that the polyphialides of the Malaysian isolate were more abundant. The difficulties of assigning this species to one of the sections of the genus 

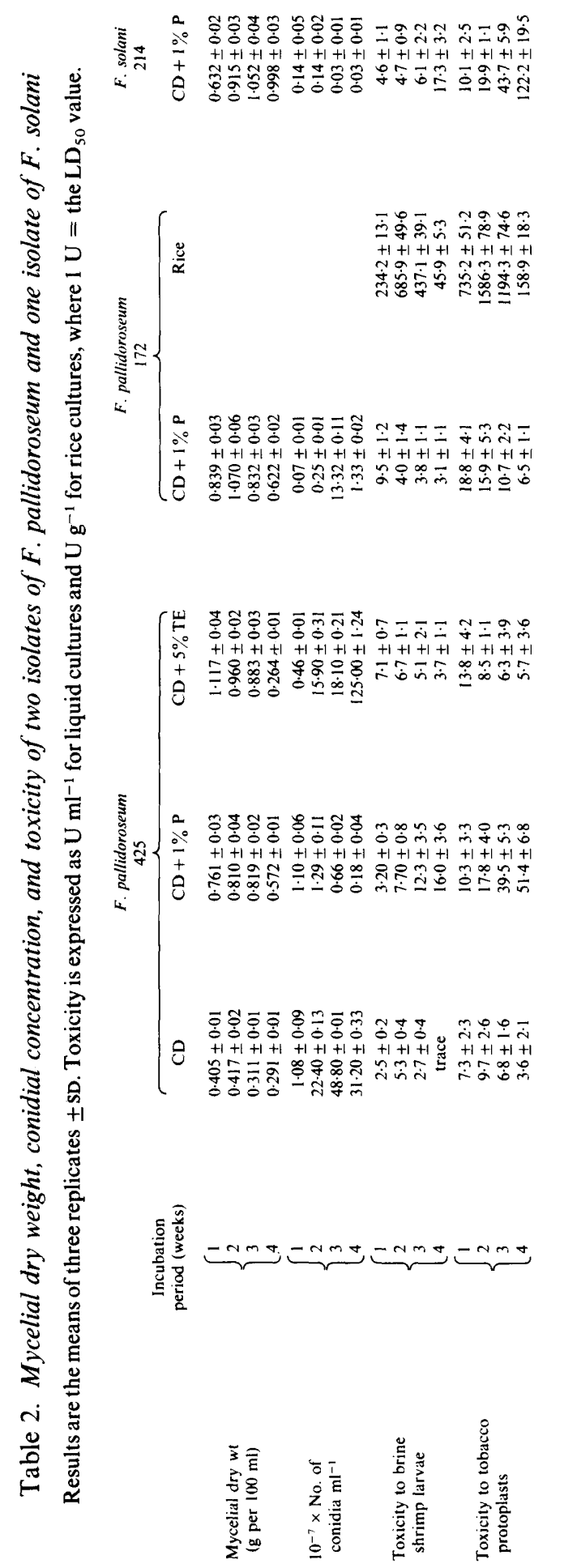

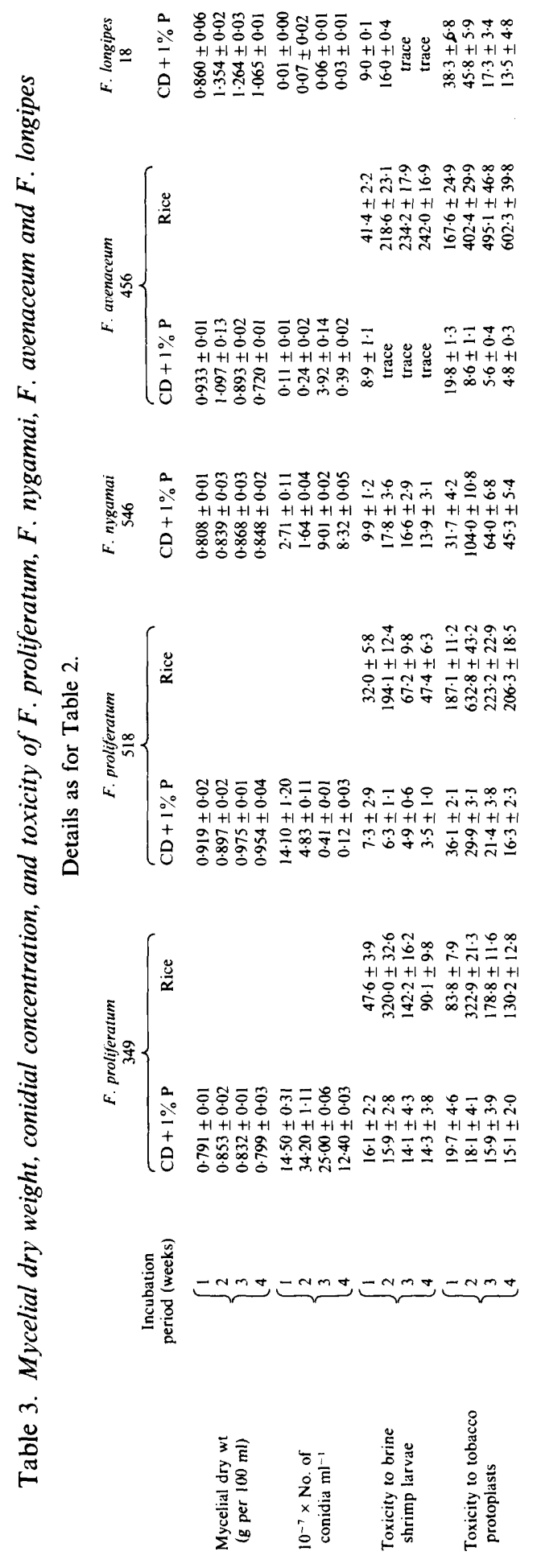


Table 4. Mycelial dry-weight, conidial concentration and toxicity of $F$. chlamydosporum

Details as for Table 2.

\begin{tabular}{|c|c|c|c|c|c|}
\hline & \multirow{2}{*}{$\begin{array}{c}\text { Incubation } \\
\text { period (weeks) }\end{array}$} & \multicolumn{2}{|c|}{ Isolate 447} & \multicolumn{2}{|c|}{ Isolate 188} \\
\hline & & $\mathrm{CD}+1 \% \mathrm{P}$ & Rice & $\mathrm{CD}+1 \% \mathrm{P}$ & Rice \\
\hline $\begin{array}{l}\text { Mycelial dry wt } \\
\text { (g per } 100 \mathrm{ml} \text { ) }\end{array}$ & $\left\{\begin{array}{l}1 \\
2 \\
3 \\
4\end{array}\right.$ & $\begin{array}{l}0.919 \pm 0.02 \\
0.879 \pm 0.02 \\
0.917 \pm 0.02 \\
0.871 \pm 0.01\end{array}$ & & $\begin{array}{l}1 \cdot 024 \pm 0.03 \\
1 \cdot 112 \pm 0 \cdot 11 \\
1 \cdot 237 \pm 0 \cdot 10 \\
1 \cdot 214 \pm 0.09\end{array}$ & \\
\hline $\begin{array}{r}10^{-7} \times \text { No. of } \\
\text { conidia } \mathrm{ml}^{-1}\end{array}$ & $\left\{\begin{array}{l}1 \\
2 \\
3 \\
4\end{array}\right.$ & $\begin{array}{c}0 \cdot 01 \pm 0 \cdot 00 \\
0 \\
0 \\
0\end{array}$ & & $\begin{array}{c}0.03 \pm 0.01 \\
0.02 \pm 0.00 \\
0 \\
0\end{array}$ & \\
\hline $\begin{array}{l}\text { Toxicity to brine } \\
\text { shrimp larvae }\end{array}$ & $\left\{\begin{array}{l}1 \\
2 \\
3 \\
4\end{array}\right.$ & $\begin{array}{r}15 \cdot 6 \pm 1 \cdot 1 \\
6 \cdot 3 \pm 0 \cdot 4 \\
4 \cdot 3 \pm 0 \cdot 4 \\
2 \cdot 5 \pm 0 \cdot 2\end{array}$ & $\begin{array}{l}428 \cdot 2 \pm 42 \cdot 3 \\
687 \cdot 6 \pm 47 \cdot 8 \\
576 \cdot 7 \pm 28 \cdot 2 \\
148 \cdot 4 \pm 16 \cdot 8\end{array}$ & $\begin{array}{l}9.5 \pm 0.9 \\
3 \cdot 2 \pm 0 \cdot 2 \\
2 \cdot 8 \pm 0 \cdot 1 \\
2 \cdot 2 \pm 0.2\end{array}$ & $\begin{array}{c}40 \cdot 9 \pm 4 \cdot 6 \\
134 \cdot 6 \pm 12 \cdot 9 \\
292 \cdot 2 \pm 35 \cdot 8 \\
232 \cdot 6 \pm 24 \cdot 6\end{array}$ \\
\hline $\begin{array}{l}\text { Toxicity to tobacco } \\
\text { protoplasts }\end{array}$ & $\left\{\begin{array}{l}1 \\
2 \\
3 \\
4\end{array}\right.$ & $\begin{array}{r}17.2 \pm 1.9 \\
7.0 \pm 0.8 \\
7.5 \pm 0.9 \\
4.3 \pm 0.6\end{array}$ & $\begin{array}{r}898 \cdot 6 \pm 38.9 \\
1634.9 \pm 76 \cdot 1 \\
1225.9 \pm 67 \cdot 3 \\
303.3 \pm 11 \cdot 4\end{array}$ & $\begin{array}{l}17 \cdot 2 \pm 1 \cdot 6 \\
15 \cdot 5 \pm 1 \cdot 1 \\
10 \cdot 3 \pm 1 \cdot 4 \\
11 \cdot 5 \pm 2 \cdot 2\end{array}$ & $\begin{array}{c}60 \cdot 7 \pm 6 \cdot 1 \\
178 \cdot 9 \pm 11 \cdot 2 \\
396 \cdot 6 \pm 21 \cdot 3 \\
351 \cdot 7 \pm 12 \cdot 4\end{array}$ \\
\hline
\end{tabular}

established by Wollenweber \& Reinking (1935) were discussed by Burgess \& Trimboli (1986). $F$. proliferatum, $F$. nygamai and $F$. longipes have not previously been recorded in the Malaysian Peninsula. Also, as far as we are aware, this is the first report of an association of $F$. oxysporum var. redolens and $F$. solani with human diseases from this area.

Maximum mycelial growth, expressed as dry weight, of all isolates on all liquid media approached or exceeded $1 \mathrm{~g}$ per $100 \mathrm{ml}$ apart from isolate 425 of $F$. pallidoroseum grown on unsupplemented Czapek-Dox (CD), which only reached values of about $400 \mathrm{mg}$ per $100 \mathrm{ml}$ (Tables 2-4). These values were generally achieved after incubation for 1 or 2 weeks. Since isolate 425 of $F$. pallidoroseum grew poorly on $\mathrm{CD}$ and produced low toxin titres compared with the same isolate growing on $\mathrm{CD}+1 \% \mathrm{P}$ (Table 2), peptone was added to $\mathrm{CD}$ in all subsequent experiments. Additionally, isolates obtained from diseased tobacco were grown on CD supplemented with $5 \%$ tobacco extract (CD $+5 \% \mathrm{TE})$. Some cultures showed a pronounced decrease in dry weight after incubation for 4 weeks, suggesting autolysis, but in one instance (isolate 425 of $F$. pallidoroseum growing on $\mathrm{CD}+5 \% \mathrm{TE}$; Table 2), this was paralleled by an increase in sporulation from $1.81 \times 10^{8}$ to $1.25 \times 10^{9}$ conidia $\mathrm{ml}^{-1}$.

Sporulation was dependent on isolate and medium (Tables 2-4). The highest value, $2.6 \times 10^{10}$ conidia $\mathrm{ml}^{-1}$, was reached by isolate 381 of $F$. oxysporum var. redolens after 1 week's growth on $\mathrm{CD}+1 \% \mathrm{P}$ (data not shown). In contrast, neither isolate of $F$. chlamydosporum sporulated appreciably (Table 4 ) and $F$. acuminatum did not sporulate at all on this medium (data not shown).

The $\mathrm{pH}$ of all liquid cultures rose during incubation, possibly reflecting the uptake of nitrate. Maximum values were generally in the range $\mathrm{pH} 8-9$ and were normally attained after 4 weeks.

Tobacco mesophyll protoplasts were more sensitive than brine shrimp larvae to toxin preparations of all isolates except $F$. solani isolated from human eye (isolate 610) grown on $\mathrm{CD}+1 \% \mathrm{P}$ and $F$. oxysporum var. redolens (isolate 381 ) isolated from human nails and grown on $\mathrm{CD}+1 \% \mathrm{P}$ (data not shown). Activity of culture filtrates from these isolates was low for all four incubation periods and varied from 0 (no activity) to $15.7 \mathrm{U} \mathrm{ml}^{-1}$ when assayed with brine shrimp larvae and from a trace to $1.7 \mathrm{U} \mathrm{ml}^{-1}$ when assayed with tobacco mesophyll protoplasts (data not shown). Other species that produced little toxin were $F$. acuminatum and $F$. concolor (brine shrimp assay maxima 11.8 and 8.3 units respectively and protoplast assay 24.3 and 20.7 respectively; data not shown).

Species that were isolated from rice were grown on this substrate as well as CD $+1 \% \mathrm{P}$. Far higher titres were obtained from the rice cultures than the liquid cultures when the comparison 
was made between results expressed as $\mathrm{U} \mathrm{g}^{-1}$ and $\mathrm{U} \mathrm{ml}^{-1}$, respectively. For example, isolate 447 of $F$. chlamydosporum reached a value of $1634.9 \mathrm{U} \mathrm{g}^{-1}$ in the tobacco mesophyll protoplasts assay when grown on rice for 2 weeks but only $7.0 \mathrm{U} \mathrm{ml}^{-1}$ when grown for the same period on $\mathrm{CD}+1 \% \mathrm{P}$ (Table 4). One possible explanation for this, apart from the effect of the medium, is that the methanol used to extract the rice cultures was a better solvent for the toxins than the water provided by the aqueous media. In addition, the rice cultures were homogenized, allowing the extraction of the mycelium itself.

The activity of extracts of rice cultures was generally 1.5-3 times greater when assayed against tobacco mesophyll protoplasts than when assayed against brine shrimp larvae. For $F$. pallidoroseum (isolate 172 ), $F$. proliferatum (isolate 349 ) and $F$. chlamydosporum (isolates 188 and 447) the congruence of the two assays was particularly striking, suggesting that toxicity of the preparations to both organisms was caused by the same compounds (Tables 2-4). Toxin production by $F$. pallidosporum isolate 425 (Table 2) and $F$. solani isolates 505 and 527 (data not shown), which were obtained from diseased tobacco, was not enhanced by including extracts of their host plant, but rather toxin titres were reduced relative to those obtained on $C D+1 \% P$. Robeson \& Strobel (1985) reported the same phenomenon when Alternaria helianthi was grown in CD supplemented with an extract of its host, sunflower. When the weight of the sunflower leaves extracted was more than $1 \mathrm{~g}$ and the extract dissolved in 1 litre of $\mathrm{CD}$, toxin production was reduced. In contrast, at lower concentrations, the extract promoted toxin production.

Toxicity of the culture filtrates or the extracts of rice cultures was not destroyed by boiling for 10 min (results not shown).

Uninoculated liquid culture media and extracts of uninoculated rice were toxic to neither brine shrimp larvae nor tobacco mesophyll protoplasts.

The data reported in this paper suggest that Fusarium species are prevalent in the Malaysian Peninsula and that they are frequently associated with plants in which they may cause disease. Since they are capable of synthesizing toxins in culture it is highly probably that they also do so in planta. Ingestion of such plant material could be a health hazard to man and animals. We are currently attempting to establish the chemical identity of the mycotoxins.

B.S. thanks the Association of Commonwealth Universities for financial support during his sabbatical leave in this Department and the Universiti Sains Malaysia for granting his leave. Isolates 381 and 610 were kindly provided by Mrs Darah Ibrahim of the School of Medical Sciences, Universiti Sains Malaysia.

\section{REFERENCES}

Bergers, W. W. A., VAN Der Stap, J. G. M. \& Kientz, C. E. (1985). Trichothecene production in liquid stationary cultures of Fusarium tricinctum NRRL 3299 (synonym: $F$. sporotrichioides): comparison of quantitative brine shrimp assay with physicochemical analysis. Applied and Environmental Microbiology 50, 656-662.

BooTH, C. (1971). The Genus Fusarium. Kew, UK: Commonwealth Mycological Institute.

Воотн, С. (1977). Fusarium: Laboratory Guide to the Identification of the Major Species. Kew, UK: Commonwealth Mycological Institute.

Burgess, L. W. \& Trimboli, D. (1986). Characterization and distribution of Fusarium nygamai, sp. nov. Mycologia 78, 223-229.

Din, I. \& SAlleh, B. (1986). Seed-borne pathogenic fusaria on rice, maize and mungbean. In $2 n d$ International Conference on Plant Protection in the Tropics, 17-20 March 1986, Genting Highlands, Malaysia, (extended abstracts), p. 113.

Finney, D. J. (1980). Probit Analysis. Cambridge: Cambridge University Press.
GORDON, W. L. (1960). The taxonomy and habitats of Fusarium species from tropical and temperate regions. Canadian Journal of Botany 38, 643-658.

HAIG, A. M., JR (1982). Chemical Warfare in Southeast Asia and Afghanistan, pp. 506-537. Report to Congress from the Secretary of State, Washington: US Department of State Special Report no. 98.

HANSEN, H. N. \& SMITH, R. E. (1932). The mechanisms of variation in imperfect fungi: Botrytis cinerea. Phytopathology 22, 953-964.

JoFFE, A. Z. (1978). Fusarium poae and Fusarium sporotrichioides as principal causal agents of alimentary toxic aleukia. In Mycotoxic Fungi, Mycotoxins and Mycotoxicosis, pp. 21-86. Edited by T. D. Wyllie \& L. G. Morehouse. Berlin: Marcel Dekker.

JofFe, A. Z. (1986). Fusarium Species - Their Biology and Toxicology. New York: John Wiley.

LIM, G. (1969). Fusarium wilt of marigolds. Mycopathologia et mycologia applicata 39, 345-347.

LIM, G. (1982). Some prevalent fungal diseases of cultivated plants in Singapore and their control. In Proceedings of the 1st International Conference on 
Plant Protection in the Tropics, pp. 189-197. Edited by G. Varghese. Kuala Lumpur: Malaysian Plant Protection Society.

LIU, P. S. (1977). A Supplement to a Host List of Plant Diseases in Sabah, Malaysia. Kew, UK : Commonwealth Mycological Institute.

Marasas, W. F. O., Wehner, F. C., van Rensburg, S. J. \& VAN SCALKWYK, D. J. (1981). Mycoflora of corn produced in human esophageal cancer areas in Transkei, Southern Africa. Phytopathology 71, 792796.

Marasas, W. F. O., Nelson, P. E. \& Toussoun, T. A. (1984). Toxigenic Fusarium Species: Identity and Mycotoxicology. University Park, USA : Pennsylvania State University Press.

Mirocha, C. J., Pathre, S. V., Schauerhamer, B. \& Christensen, C. M. (1976). Natural occurrence of Fusarium toxins in feedstuff. Applied and Environmental Microbiology 32, 553-556.

Mirocha, C. J., Pathre, S. V. \& Christensen, C. M. (1977). Zearalenone. In Mycotoxins in Human and Animal Health, pp. 345-364. Edited by J. V. Rodricks \& C. W. Hesseltine. Illinois: Pathotox Publishers.

Mirocha, C. J., Watson, S. \& Hayes, W. (1982). Occurrence of trichothecenes in samples from Southeast Asia associated with 'yellow rain'. Proceedings of the 4th International IUPAC Symposium on Phytotoxins, Vienna, 1-3 Sept. 1982, pp. 130133.

Mirocha, C. J., Pawlosky, R. A., Chatterjee, K., WATSON, S. \& HAYES, W. (1983). Analysis of Fusarium toxins in various samples implicated in biological warfare in Southeast Asia. Journal of the Association of Official Analytical Chemists 66, 14851499.

Nelson, P. E., Toussoun, T. A. \& Marasas, W. F. O. (1983). Fusarium Species: an Illustrated Manual for Identification. University Park, USA : Pennsylvania State University Press.

Power, J. B. \& Chapman, J. V. (1985). Isolation, culture and genetic manipulation of plant protoplasts. In Plant Cell Culture: a Practical Approach, pp. 37-66. Edited by R. A. Dixon. Oxford: IRL Press.

Robeson, D. J. \& Strobel, G. A. (1986). The influence of plant extracts on phytotoxin production and growth rate of Alternaria helianthi. Journal of Phytopathology 117, 265-269.

Rosen, R. T. \& Rosen, J. D. (1982). Presence of four Fusarium mycotoxins and synthetic material in 'yellow rain'. Evidence for the use of chemical weapons in Laos. Biomedical Mass Spectrometry 9 , 443-450.
Salleh, B. \& Sulaiman, B. (1984). Fusaria associated with naturally diseased plants in Penang. Journal of Plant Protection in the Tropics 1, 47-53.

Salleh, B. \& Zunaidah, A. (1984). Soil fusaria in Penang Island. In 7th Malaysian Microbiology Symposium, 18-20 Nov. 1984, Penang (abstracts), pp. 4748.

SingH, K. G. (1973). A Check-list of Host and Disease in Peninsular Malaysia. Kuala Lumpur: Ministry of Agriculture and Fisheries Publication no. 132.

SNYDER, A. P. (1986). Qualitative, quantitative and technological aspects of the trichothecene mycotoxins. Journal of Food Protection 49, 544-569.

Strange, R. N., Pippard, D. J. \& Strobel, G. A. (1982). A protoplast assay for phytotoxins produced by Phytophthora drechsleri. Physiological Plant Pathology 20, 359-364.

Tanaka, T., Hasegawa, A., Matsuki, Y., Lee, U. \& UENO, Y. (1986). A limited survey of Fusarium mycotoxins nivalenol, deoxynivalenol and zearalenone in 1984 UK harvest wheat and barley. Food Additives and Contaminants 3, 247-252.

Thanutong, P., Furusawa, I. \& Yamamoto, M (1983). Resistant tobacco plants from protoplasts derived from calluses, selected for their resistance to Pseudomonas and Alternaria toxins. Theoretical and Applied Genetics 66, 209-215.

Thompson, A. \& Johnston, A. (1953). A Host List of Plant Diseases in Malaysia. Kew, UK: Commonwealth Mycological Institute.

Turner, G. J. (1971). Fungi and Plant Diseases in Sarawak. Kew, UK: Commonwealth Mycological Institute.

UENO, Y. (1980). Trichothecene mycotoxins. In $A d-$ vances in Nutritional Research, vol. 3, pp. 301-353. Edited by H. H. Draper. New York: Plenum.

UENO, Y. (1983). General toxicology. In Trichothecenes - Chemical, Biological and Toxicological Aspects, pp 135-146. Edited by Y. Ueno. Amsterdam: Elsevier.

Vesonder, R. F., Ciegler, A., Rogers, R. F., BURSRIDGE, K. A., Bothast, R. J. \& JENSEN, A. H. (1978). Survey of 1977 crop year preharvest corn for vomitoxin. Applied and Environmental Microbiology 36, 885-888.

WidHolm, J. M. (1972). The use of fluorescein diacetate and phenosafranine for determining viability of cultured plant cells. Stain Technology 47, 189-194.

Williams, T. H. \& LiU, P. S. (1976). A Host List of Plant Diseases in Sabah, Malaysia. Kew, UK: Commonwealth Mycological Institute.

Wollenweber, H. W. \& Reinking, O. A. (1935). Die Fusarien, ihre Beschreibung, Schwadwirkung und Kekampfung. Berlin: Paul Parey. 